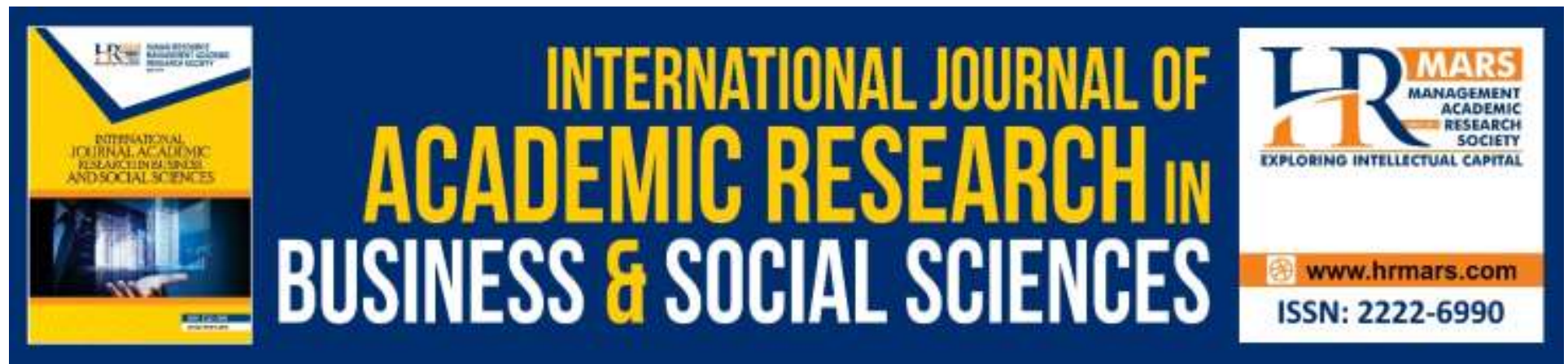

\title{
Police Leadership in Developing Youth Leaders in The Community: Positive Youth Development Perspectives in Malaysia
}

\author{
Mohd Mursyid Arshad \& Tan Hua Hong
}

To Link this Article: http://dx.doi.org/10.6007/IJARBSS/v9-i11/6710

DOI: 10.6007/IJARBSS/v9-i11/6710

Received: 14 October 2019, Revised: 28 October 2019, Accepted: 10 November 2019

Published Online: 26 November 2019

In-Text Citation: (Arshad, \& Hong, 2019)

To Cite this Article: Arshad, M. M., \& Hong, Y. H. (2019). Police Leadership in Developing Youth Leaders in The Community: Positive Youth Development Perspectives in Malaysia. International Journal of Academic Research in Business and Social Sciences, 9(11), 1434-1445.

Copyright: (c) 2019 The Author(s)

Published by Human Resource Management Academic Research Society (www.hrmars.com)

This article is published under the Creative Commons Attribution (CC BY 4.0) license. Anyone may reproduce, distribute, translate and create derivative works of this article (for both commercial and non-commercial purposes), subject to full attribution to the original publication and authors. The full terms of this license may be seen at: http://creativecommons.org/licences/by/4.0/legalcode

Vol. 9, No. 11, 2019, Pg. 1434 - 1445

http://hrmars.com/index.php/pages/detail/IJARBSS JOURNAL HOMEPAGE

Full Terms \& Conditions of access and use can be found at http://hrmars.com/index.php/pages/detail/publication-ethics 


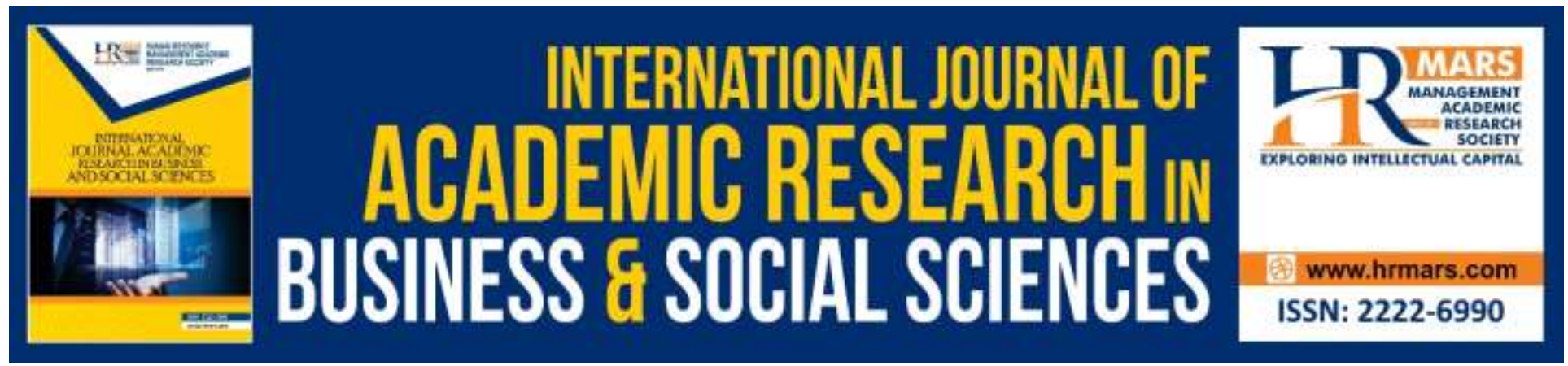

\title{
Police Leadership in Developing Youth Leaders in The Community: Positive Youth Development Perspectives in Malaysia
}

\author{
Mohd Mursyid Arshad ${ }^{1} \&$ Tan Hua Hong ${ }^{2}$ \\ ${ }^{1}$ Faculty of Educational Studies, Universiti Putra Malaysia, Serdang, 43400, Serdang, Malaysia, \\ ${ }^{2}$ Royal Malaysia Police College Kuala Lumpur, 43200, Cheras, Malaysia
}

\begin{abstract}
Youth leadership development is one of the important agenda needed in the country's development agenda as outlined in the Malaysian Youth Policy 2015. The involvement of young leaders can be strengthened through wider exposure and professional training that enhances Positive Youth Development among youths. Thus, in community context, the role of police leadership is not merely just as law enforcement officer but an icon of leadership. The authority in public order and security granted by the law to the police officer can be a positive exertion to influence the youth and it has the potential in providing that kind of learning process. Therefore, this paper will explore the process of youth development towards PYD and how police leadership enhanced youth to become leader in the community. The discussion addressed in this paper is how police leadership contributes to the process of developing youth leadership ability form at risk behavior and eventually fulfilling the overall PYD needs.

Keywords: Positive Youth Development, Police Leadership, Community Development, Leadership Development

\section{Introduction}

In line with Malaysia's vision of becoming a developed nation, the Malaysian Youth Policy 2015 aims to strengthen the leadership development process among youth. Unleashing the ability and capacity of young people to develop their willingness to take the lead would directly contribute to the successful positive youth development (PYD). In PYD, the participation of young people in leadership activities would positively encourage developmental asset as it includes the youth development process (Li \& Wang, 2009).
\end{abstract}


Youth development is described as an ongoing process to meet the physical needs and social demands in building youth competencies (Delgado, 2002), which in turn, promotes positive youth development (PYD) (Lerner et al., 2005; Shbail, 2018).

However, youth development requires facilitated learning and role models that can be followed. In community perspective, Royal Malaysia Police roles in community provided under Police Act 1967, Section 3(3) are the maintenance of law and order, the preservation of the peace and security of Malaysia, the prevention and detection of crime, the apprehension and prosecution of offenders and the collection of security intelligence. Extension from those provision, Crime Prevention and Community Safety Department (JPJKK) was form in June 2014 under Royal Malaysia Police transformation program.

Generally, the functions of the police department are crime prevention, eliminate criminal opportunity, eliminate crime intention, empower the community, handling public negative perception and as community advisors (Haberfeld, 2006; Mutumburanzou, 2018). Under the community advisors role, the Royal Malaysia Police playing a consultative role to the community, educational institution, business institutions, government agencies and nongovernmental agencies.

Thus, police leadership has the potential in developing that kind of learning process for youth in the community. Focusing on the PYD process serves as the basis for the development of positive youth self-potential elements (Lerner et al., 2015), which principally comprises with empirical understanding to reveal the potential of police leadership and their roles in enhancing PYD elements among youth in the community.

In Malaysia, the current policy also supports the youth development agenda at the national level through initiative to plan for the future of Malaysia in the period of 20 years started from 2015 to 2035 (Malaysian Youth Policy, 2015). From the vision of becoming a developed nation, Malaysia Youth Policy has put efforts in strengthening the leadership development process among youth and strive to be amongst the top countries in the world in economic development, citizen well-being and innovation.

However, youth leadership development may also facing some challenges. When young people often fail to see themselves as a leader and decision-makers, it is because some adult leaders do not really pass on to them the knowledge, expertise, desires and motivation to be leader (Hastings, Human \& Bell, 2011).

According to Christens and Dolan (2011) the consistency of youth leadership if not well organized, may result in young leaders not being able to participate effectively in the existing community development process, leading to youth not being closely linked to the group.

Malaysian Youth Index (2017) shows that the ability of young people to lead deteriorates, as there is a decline from 2015 index score in the category of youth leadership domain. The situation is compounded by the fact that the the government through Malaysian Youth Policy (2015) and an amendment to the Youth Societies and Youth Development Act 668 (2019) has formally re-classified youth as those between 15 to 30 years, compared to the previous range of 15 to 40 . With a younger cohort of youth leaders taking on formal leadership 
roles within the country in the near future, there is much concern regarding the leadership readiness of this group.

Considering that youth leadership development requires participative learning and role models that can be emulated, developing youth's leadership in the community through local police leader aspiration has the potential in providing that kind of development process. Therefore, this paper will discuss the police leadership towards PYD. This study also discusses the potential development of the ' $5 C^{\prime}$ ' in Positive Youth Development (PYD) and concerns involving the ability of Malaysian youths and in this context, university students and graduates and also youth in the community to lead.

Through positive youth development, the nation aspires to develop and produce future leaders who can lead organizations, communities and the nation to greater heights.

\section{Literature Review}

\section{Leadership Theories}

After reviewing more than a century literature review of leadership, there are many definitions of leadership (Maryam, 2015; Abu Daud Silong, 2009). According to Abu Daud Silong, (2009), after revised the literature on leadership definition, he concluded leadership is about influence, and to influence a leader must have followers, and the process of influencing occurs in a context towards some kind of goals. The same context also defines by. The essential elements that related to leadership are influence, follower and goals (Northouse, 2016; 2010; Hughes, Ginnett \& Cuphy, 2015). When discuss about Leadership theories, it can be categorized under few school of thought like traits theory, behavioral theories, situational theories and integrative theories.

Traits theory, at the beginning of leadership study, people believe in the Great Man Theory that can be traced back to the early 1900s (Hughes et al., 2015). The fundamental concept, in theory, is believed leaders are born and not made (Achua \& Lussier, 2013). The researcher tries to identify the traits that refer to trends in a person behavior (Hughes et al., 2015) and what made a great leader (Northouse, 2016; 2010). Moving from that, Trait theory emerged and after taking into consideration of previous research on traits leadership, Northouse (2010) concluded significant leadership traits are central to intelligence, self-confidence, determination, integrity and sociability.

Extension from traits theory, some researchers are not happy with the result to begin to look into behavior to explain leadership effectiveness. According to Silong (2009), the critical researchers in behavioral theories are: -

i) University of lowa studies - Identifies three leadership style ranging from autocratic to democratic to laissez-faire approaches.

ii) University of Michigan studies - Identifies two leadership styles that lie on a continuum one end of the continuum focusing on task-oriented behaviors and other end concentrates on people-oriented behaviors, 
iii) University of Ohio studies - Identifies two primary leadership behaviors - consideration and initiating structure that in combination provide four leadership styles: high in consideration and initiating structure, low in consideration and initiating structure, high in consideration and low in initiating structure and vice versa.

iv) Mouton - Blake studies - Introduces the Leadership Grip that identifies five leadership styles - the impoverished leadership, authority-compliant leadership, middle of the road leadership, country club leadership and team leadership.

v) Mintzberg - Introduces ten managerial roles that can be assumed by managers/leaders.

vi) Yukl - Identifies 15 dimensions of managerial/leadership behavior that have some similarities to Mintzberg's roles.

vii) Madinah Mohamad and Abu Daud Silong - Identifies various styles of community leaders in Malaysia, the most effective being the democratic style using two-way communication.

viii) Abu Daud Silong - Indicates that to be more effective, public sector leaders must change their traditional role of command and control to a more collaborative style that engages the people.

As suggested by Fiedler (1967), Hersey and Blanchard (1985), stated that leader's effectiveness influence by the situation. Fiedler (1967) contingency theory focuses on three dimensions, the leader-member relationship, task structure, and leader's position of power. As leadership style has to fix accordingly to follower developmental level, therefore in the case of Malaysia, the leader needs to take into consideration the background of the follower, which is multi races before using the appropriate style (Mohamad \& Silong, 2009).

Integrative theories try to combine traits, behaviors and situation to explain influencing and successful leaders-follower relationship (Achua \& Lussier, 2013). These theories include Transactional and Transformational leadership by Burns (1978), Bass (1985), which is the concern on how some leader inspire and empower their follower to achieve goals (Northouse, 2010). Beside that servant leadership by Greenleaf (1977) also emphasized focusing on follower not the leaders as the leader putting follower interest above of their own in realizing organizational goals (Mohamad \& Silong, 2009).

\section{Police Leadership}

The core tasks for police leaders included problem-solving; creating a shared vision; engendering organizational commitment; providing care for subordinates; as well as driving and managing change (Pearson-Goff \& Herrington, 2013). Beside those others scholars did highlighted finding on police leadership style and competencies found to be identical with transformational leadership (Shim, 2015; Masal, 2015; Farkas, 2014; Vito George, 2014; Kirby, 2014; Miller, 2014; 
Swid, 2014; Indrayanto, 2013), servant leadership style (Massey, 2015) authentic leadership (Neyroud, 2011), command and control (Shane 2010; Batts, 2012).

With the nature of their working environment and the exposure of leadership experience, police leaders have potential to shape our youth leadership development. In police leadership style also discussed in which the personality of the leader stimulates change through the raising of motivation, morale, and a consciousness of mission (Haberfeld, 2006).

\section{Positive Youth Development}

Positive youth development (PYD) perspective basically combines two main ideas. The first perspective is that youths possess the strength as displayed through the development of their ability in cognitive, emotion, social and behavioral changes (Phelps et al., 2009; Gestsdottir et al., 2011). Furthermore, the second perspective is the hypothesis assuming that the PYD element will increase when the youth strength is compatible with the strength to react to their surrounding (Benson, Skala, Hamilton, \& Sesma, 2006), for a healthy development in their ecology.

The individual development process in the PYD context involves adaptation of developmental regulations between youth strength and asset development within a particular ecology (Phelps et al., 2009). Specifically, the PYD perspective can be narrowed down to the following:

"The Positive Youth Development (PYD) perspective is an orientation to young people that has arisen because of interest among developmental scientists in using development systems, or dynamic, models of human behavior and development for understanding the plasticity of human development and the importance of relations between individuals and their real-world ecological settings as bases of variation in the course of human development"

(Sibereisen \& Lerner, 2007, p.3)

The term 'plasticity' refers to the potential for a more systematic change in human development, which instills positive elements (Lerner et al., 2005; Lerner, Brittian \& Fay, 2007). Therefore, the process of systematic change in youth development requires internal and external support (Lerner et al., 2005). According to Theokas et al. (2005), the combination of internal and external situations for the development of PYD elements above mentioned are known as the ecological and individual assets (Lerner et al., 2010), that consist of five elements ' $5 C^{\prime}$ ' (Lerner et al., 2005), illustrated in Figure 1 as follows: 


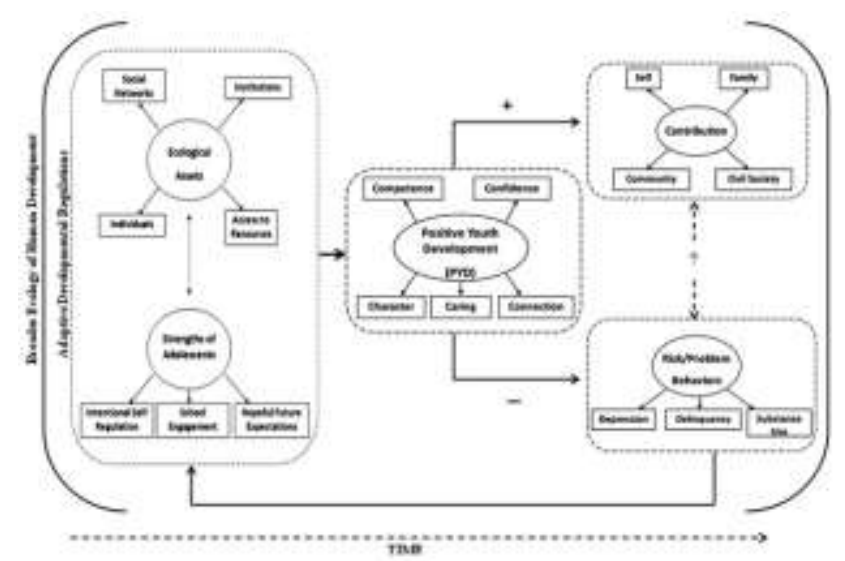

Figure 1. The relational, developmental systems model of Positive Individual involved in PYD (Lerner et al., 2005, p. 7)

The internal asset is an element that guides youths to make choices related to their strengths, that is their hopeful future expectation, internal self-regulation and positive school engagement. Meanwhile, the external assets are ecological assets mostly related to positive experiences obtained from others, and the institutions they are involved with (Lerner et al., 2012). This may lead to individual joined benefit as the context of relationship with PYD consist of five elements ' $5 \mathrm{C}$ ' (competence, confidence, character, connection and caring) (Lerner et al., $2005 ; 2015)$.

\section{Discussion \\ Police Leadership and Youth Leadership from PYD Perspectives}

Findings from the most recent Malaysian Youth Index (2017) indicate that this is currently the situation in Malaysia, i.e. youth's readiness to lead is decreasing. In addition, there are concerns about the ability of Malaysian youth to lead. The situation is compounded by the fact that the government through Malaysian Youth Policy (2015) and an amendment to the Youth Societies and Youth Development Act 668 (2019) has formally re-classified youth as those between 15 to 30 years, compared to the previous range of 15 to 40 . With a younger cohort of youth leaders taking on formal leadership roles within the country in the near future, there is much concern regarding the leadership readiness of this group.

The cycle of learning, actions and positive attitude of young people may be developed from leadership development programs which that can be an indicator of PYD (Lerner et al., 2005; Silbereisen \& Lerner, 2007; Lerner et al., 2011). Through police leadership roles, youth have the opportunity to develop individual assets through skills, establish youth leadership and cohesion, and create a harmonious social partnership between youth and adults.

The profit gained by the youth through leadership mentoring is related to the requirements for successful youth development. Futhermore, it provides opportunities for youth to gain access to the culture they are interested in using the external resources. 
This will build each of the ' 5 Cs ' components directly in the creation of productive youth, which may eventually be the youth's contribution (Lerner et al., 2013).

\section{Conclusion}

Based on the discussion above explain the role of police leadership is not merely just as law enforcement officer but can be an icon of leadership in the community especially among the youth. The authority in public order and security granted by the law to the police officer can be a positive exertion to influence the youth. A non-enforcement role approach is a strategy to nurture the positive relationship between the Royal Malaysia Police officers and the youth. Once the relationship establishes, we hoping the positive values can be indoctrinated to the mind of the youth.

The local police leaders at the district and station levels such as Officer in Charge of Police District (OCPD), Officer in Charge of Police Station (OCS) and School Liaison Officer may play a significant role to engage the youth under their jurisdiction. They can guide the specifically targeted youth group with their personal experience on how they went thru their growing period and especially their working experience as previous researcher found that police leadership identical with transformational leadership, servant leadership style, authentic leadership and command and control. These can provide a pool of experience and knowledge to be share with the youth.

More efforts should be made to explore the Malaysian youths' involvement in leadership development via police leadership that representing icon in the community, which may contribute to positive youth development. Efforts to develop youth through the process of leadership can raise positive values among youth.

Conceptually, the idea from discussion will explore how youth, who participated in leadership programs that incorporate intervention program for youth at risk behavior, learned and built positive values via the police leadership. The discussions suggest that the influence of police leadership is one of the factors that assist in the formation of new leadership potentials among youths in the community.

All in all, police leadership is one of the insightful mechanisms that helps in developing leadership abilities among youth. Youth learning occurs in the locus of the local police leaders and not limited only to the positive development between police leaders and youth. In fact, youth leadership development also occurred through police's organizational community especially encouraging youth at risk behavior to become positive youth.

Access obtained from a local police leader-owned network helps accelerate the development of their ecological assets that help to improve PYD. Agans et al. (2014) states that youth are often left out in the context of social activity and positive connection. Therefore, the construction of an external network is necessary for the youth to exhibit positive values that induce bonding with other individuals and institutions as well as helping to build youth capacity in connection towards PYD (Agans et al., 2014). Provision of a platform by mentors helps to bond mutually beneficial relationships between 
individuals and peers, institutions and communities.

In addition, the positive values addressed from the PYD viewpoint also analyzed mainstream youth services, including civic and organizational services. It can therefore be seen that the values of the PYD have a strong relationship with values of leadership shaped by the police leadership.

Therefore, it can be seen that the PYD emanated through strong relationship and bond between the young leaders and the leadership community of practice in the development process. More initiatives that link police institution, public sector and corporate in the form of positive youth development should be provided to youth to enhance the leadership learning and eventually the overall holistic, balanced and entrepreneurial traits expected from them as espoused in the Malaysian Youth Policy 2015-2035.

\section{Acknowledgement}

This research was supported by Universiti Putra Malaysia (UPM) and Royal Malaysia Police College Kuala Lumpur, Malaysia.

\section{Corresponding Author}

Mohd Mursyid Arshad (PhD), Department of Professional Development \& Continuing Education, Faculty of Educational Studies, Universiti Putra Malaysia, 43400 UPM Serdang, Selangor Darul Ehsan, Malaysia.

Email: m_mursyid@upm.edu.my

\section{References}

Abu, D. S. (2009). Leadership theories, research and practices: Framing future leadership thinking. Inaugural Lecture Series, Serdang: Universiti Putra Publisher.

Achua, C. F., \& Lussier, R. N. (2013). Leadership Theory, Application, and Skill Development (5th ed.). Singapore: South-Western, Cengage Learning.

Indrayanto, A., Burgess, J., Dayaram, K. N. (2014). A case study of transformational leadership and para-police performance in Indonesia. Policing: An International Journal of Police Strategies \& Management, 37(2), 373-388. http://doi.org/10.1108/PIJPSM-03-20130029

Agans, J. P., Champine, R. B., DeSouza, L. M., Mueller, M. K., Johnson, S. K., \& Lerner, R. M. (2014). Activity involvement as an ecological asset: Profiles of participation and youth outcomes. Journal of Youth and Adolescence, 43, 919-932. http://doi.org/10.1007/s10964-0140091-1

Anthony, W., Batts, S. M. S., and E. S. (2012). Police Leadership Challenges in a Changing World. National Institute of Justice, July(2010), 1-20.

Benson, P. L., Scales, P. C., Hamilton, S. F., \& Sesma, A. J. (2006). Positive youth development: Theory, research, and applications. In R. M. Lerner (Ed.), Theoretical models of human development. Volume 1 of Handbook of Child Psychology (6th ed.) (pp. 894-941). Editors- 
INTERNATIONAL JOURNAL OF ACADEMIC RESEARCH IN BUSINESS AND SOCIAL SCIENCES

Vol. 9, No. 11, November, 2019, E-ISSN: 2222-6990 @ 2019 HRMARS

in-chief: W. Damon \& R. M. Lerner. Hoboken, NJ: Wiley.

Christens, B. D., \& Dolan, T. (2011). Interweaving Youth Development, Community Development, and Social Change Through Youth Organizing. Youth \& Society, 43, 528-548. http://doi.org/10.1177/0044118X10383647

Delgado, M. (2002). New frontiers for youth development in the twenty-first century revitalizing youth development. New York: Columbia University Press.

Vito, F. G., Higgins, G., \& Denney, A. (2014). Transactional and transformational leadership. Policing: An International Journal of Police Strategies \& Management, 37(4), 809-822. http://doi.org/10.1108/PIJPSM-01-2014-0008

Fisher, A., \& Kirby, S. (2014). Implementing the citizen focus agenda: a case study in police leadership. International Journal of Leadership in Public Services, 10, 142-156. http://doi.org/10.1108/IJLPS-06-2014-0005

Gestsdottir, S., Urban, J. B., Edmond, P., Lerner, J. V., \& Lerner, R. M. (2011). Intentional SelfRegulation, Ecological Assets, and Thriving in Adolescence: A Developmental Systems Model. In R. M. Lerner, J. V. Lerner, E. P. Bowers, S. Lewin-Bizan, S. Gestsdottir, \& J. B. Urban (Eds.), Thriving in childhood and adolescence: The Role of self-regulation processes. New Directions for Child and Adolescence Development, 133, 61-76.

Haberfeld, M. R. (2006). Police Leadership. Upper Saddle River: Prentice Hall

Hastings, L. J., Human, N., \& Bell, L. C. (2011). Developing a Paradigm Model of Youth Leadership Development and Community Engagement : A Grounded Theory. Journal of Agricultural Education, 52(1), 19-29. doi:10.5032/jae.2011.01019

Hassanzadeh, M., Silong, A. D., Asmuni, A., \& Wahat, A. N. W. (2015). Developing Effective Global Leadership. Journal of Educational and Social Research, 5(3), 15-24. http://doi.org/10.5901/jesr.2015.v5n3p15

Hernez-broome, G., \& Hughes, R. L. (n.d.). Leadership development: Past, present, and future. Human Resource Planning, 24-32.

Jo, Y., \& Shim, H. S. (2015). Determinants of police job satisfaction: Does community matter? International Journal of Law, Crime and Justice, 43(2), 235-251. http://doi.org/10.1016/j.ijlcj.2014.09.002

Lerner, R. M., Lerner, J. V., Almerigi, J., Theokas, C., Phelps, E., Gestsdottir, S., Naudeau, S., Jelicic, H., Alberts, A.E., Ma, L., Smith, L.M., Bobek, D.L., Richman-Raphael, D., Simpson, I., Christiansen, E.D., \& von Eye, A. (2005). Positive youth development, participation in community youth development programs, and community contributions of fifth grade adolescents: Findings from the first wave of the 4-H study of positive youth development. Journal of Early Adolescence. 25(1): 17-71.

Lerner, R. M., von Eye, A., Lerner, J. V., Lewin-Bizan, S., \& Bowers, E. P. (2010). The meaning and measurement of thriving: A view of issues. Journal of Youth and Adolescence, 39 (7), 707719.

Lerner, R. M., Lerner, J. V., Lewin-Bizan, S., Bowers, E. P., Boyd, M., Mueller, M., Schmid, K., Napolitano, C. (2011). Positive youth development: Processes, programs, and problematics. Journal of Youth Development, 6(3), 40-64. 
Lerner, R. M., Bowers, E. P., Geldholf, G. J., Gestsdottir, S., \& Desouza, L. (2012). Promoting positive youth development in the face of contextual changes and challenges: The roles of individual strengths and ecological assets. New Directions for Youth Development, 135(1), 119-28. doi: 10.1002/yd.20034

Lerner, R. M., Napolitano, C. M., Boyd, M. J., Mueller, M. K., \& Callina, K. S. (2013). Mentoring and positive youth development. In D. L. DuBois, \& M. J. Karcher (Eds.), The handbook of youth mentoring (2nd ed.). (pp. 17-27). Thousand Oaks: Sage Publications Inc.

Lerner, R. M., Lerner, J. V., Bowers, E. P. \& Geldholf, G. J. (2015). Positive youth development: A relational developmental systems model. In R.M. Lerner, W. F. Overton, \& P. C. M. Molenaar (Eds.), The handbook of child psychology and developmental science (7th ed.). (pp. 607-651). New Jersey: John Wiley and Sons Inc.

Li, G., \& Wang, B. (2009). Adolescent Leadership Development: A Review. International Conference on Teaching and Computational Science (WTCS 2009) Proceedings (pp. 753758). Shenzhen: Advances in Intelligent and Soft Computing.

Madinah, M., \& Sllong, A. D. (2010). Leadership competencies and development for ccommunity leaders in Malaysia. The Journal of International Social Research, 3(14).

Malaysian Youth Policy (2015). Institut Penyelidikan Pembangunan Belia Malaysia. Putrajaya: Kementerian Belia dan Sukan Malaysia.

Malaysian Youth Index (2017). Institut Penyelidikan Pembangunan Belia Malaysia. Putrajaya: Kementerian Belia dan Sukan Malaysia.

Mary B. Sarver, H. M. (2014). Police chief leadership: styles and effectiveness. Policing: An International Journal of Police Strategies \& Management, 37(1), 126-143. http://doi.org/10.1108/PIJPSM-03-2013-0028

Masal, D. (2015). Shared and transformational leadership in the police. Policing: An International Journal of Police Strategies \& Management, 38(1), 40-55.

Massey, D. C. (2015). Chapter 2 I Am Second: Ethical Leadership and Self-Denial. Advances in Educational Administration (Vol. 12). Emerald Group Publishing Ltd. http://doi.org/10.1108/S1479-3660(2011)0000012005

Neyroud, P. (2011). Leading policing in the 21st century: leadership, democracy, deficits and the new professionalism. Public Money \& Management, 31(5), 347-354. http://doi.org/10.1080/09540962.2011.598346

Northouse, P. G. (2016). Leadership Theory and Practice Seventh Edition (7th Editio). Western Michigan University, USA: SAGE Publications Inc.

Pearson-Goff, M., \& Herrington, V. (2013). Police leaders and leadership development: A systematic literature review. Policing, 8(1), 14-26. Retrieved from http://policing.oxfordjournals.org/ at Cambridge University on April5, 2014

Phelps, E., Zimmerman, S., Warren, A. E. A., Jelicic, H., Eye, V. A., \& Lerner, R. M. (2009). The structure and developmental course of Positive Youth Development (PYD) in early adolescence: Implications for theory and practice. Journal of Applied Developmental Psychology, 30(5), 571-584.

Shane, J. M. (2010). Organizational stressors and police performance. Journal of Criminal Justice, 
38(4), 807-818. http://doi.org/10.1016/j.jcrimjus.2010.05.008

Silbereisen, R. K., \& Lerner, R. M. (2007). Approaches to positive youth development. London: Sage Publications.

Swid, A. (2014). Police members perception of their leaders' leadership style and its implications. Policing: An International Journal of Police Strategies \& Management, 37(3), 579-595. http://doi.org/10.1108/PIJPSM-08-2013-0085

Theokas, C. (2005). Conceptualizing and modeling individual and ecological asset components of thriving in early adolescence. The Journal of Early Adolescence, 25(1), 113-143. doi:10.1177/0272431604272460

Vera, F. B. F. A. (2014). Power and transformational leadership in public organizations. International Journal of Public Administration, 10(4), 217-232. http://doi.org/10.1080/01900699608525127

Mutumburanzou, P. (2018). The Role of Parents in the Language Development of Children with Hearing Impairment. International Journal of Academic Research in Progressive Education and Development, 7(1), 119-128.

Shbail, A. M. O. (2018). The Associations of Internal Audit Quality with Job Burnout and Job Satisfaction Based on Theory of Reasoned Action, International Journal of Academic Research in Accounting, Finance and Management Sciences 8 (2): 208-217. 